\title{
Extradigestive manifestations of Helicobacter pylori infection in children and adolescents
}

\author{
Philip M Sherman MD FRCPC, Frank YH Lin MD FRCPC
}

\begin{abstract}
PM Sherman, FYH Lin. Extradigestive manifestations of Helicobacter pylori infection in children and adolescents. Can J Gastroenterol 2005;19(7):421-424.

Helicobacter pylori infection fulfills each of Koch's postulates as a human pathogen causing chronic active gastritis. Disease consequences that develop in a subset of infected subjects include peptic ulcerations, gastric adenocarcinoma and mucosa-associated lymphoid tissue lymphoma. More recently, multiple publications have advocated a role for $H$ pylori infection in causing a variety of extraintestinal manifestations. Many of these reports suffer from being case reports or case series without adequate controls. As a result, purported manifestations may simply be coincidental in nature. On the other hand, increasing evidence supports $H$ pylori infection as a cause of sideropenic (refractory iron deficiency) anemia. Moderate evidence supports $\mathrm{H}$ pylori gastric infection as a cause of some cases of immune thrombocytopenic purpura due to molecular mimicry. Guidelines should be adjusted in accordance with advancing knowledge in the field.
\end{abstract}

Key Words: Anemia; Children; Food allergy; H pylori; Short stature; Thrombocytopenia

Since the first successful culture of Helicobacter pylori in the Searly 1980s by Barry Marshall and Robin Warren in Perth, Australia, much has been learned about this gastric pathogen (1). Each of Koch's postulates and all of Hill's criteria for causal inference have been fulfilled, showing that $H$ pylori causes a chronic active, superficial gastritis in infected individuals (1). Although most humans remain asymptomatic throughout their lifetime, a subset of infected persons develop disease complicating the gastric infection.

There is compelling evidence that $H$ pylori infection is a cause of gastric and duodenal ulcers (2). The natural history of ulcer recurrence can be altered by eradicating the gastric infection (3). Similarly, there is strong epidemiological evidence supporting the contention that $\mathrm{H}$ pylori infection increases the risk of developing gastric adenocarcinoma later in life (4). In addition, certain animal models (5) support the contention that $H$ pylori infection is a risk factor promoting the complex cascade of events that ultimately determine carcinogenesis. Multiple reports (6) indicate that at least a subset of mucosaassociated lymphoid tissue lymphomas can regress following eradication of $\mathrm{H}$ pylori infection.

Interest has arisen on the potential for related Helicobacters to cause disease in the intestinal tract and in the hepatobiliary system (reviewed by Gasbarrini et al [7]). Much of this work

\section{Manifestation extradigestive de l'infection à Helicobacter pylori chez des enfants et adolescents}

L'infection à Helicobacter pylori répond à tous les postulats de Koch au chapitre des agents pathogènes qui affectent l'être humain en causant une gastrite chronique évolutive. Les conséquences pathologiques qui se manifestent chez un sous-groupe de patients infectés sont notamment les ulcères gastro-duodénaux, le cancer de l'estomac et le lymphome du système lymphoïde des tissus. Plus récemment, de nombreuses publications ont imputé à $H$ pylori diverses manifestations extradigestives. Nombre de ces allégations ont justement l'inconvénient de n'être que des rapports de cas ou des séries de cas qui ne sont étayés par aucun système de contrôle adéquat. Les manifestations en questions pourraient donc tout aussi bien être dues au hasard. D'autre part, des preuves tendent à s'accumuler à l'effet que l'infection à $H$ pylori puisse être une cause d'anémie ferriprive (rebelle). Des preuves de degré intermédiaire incriminent l'infection à $H$ pylori comme cause de certains cas de purpura thrombocytopénique en raison de leur ressemblance moléculaire. Les directives devraient être amendées en fonction des avancées réalisées dans le domaine.

has arisen from studies in animal models. For example, it is clear that inflammatory bowel disease in interleukin-10. deficient mice is much more severe in mice that are colonized with Helicobacter hepaticus compared with animals clear of the infection (8). Similarly, colitis in the cotton-topped tamarin appears dependent on colonization of the large bowel by a novel Helicobacter (9).

The potential for $\mathrm{H}$ pylori - or a novel related Helicobacter species - to cause disease in the human hepatobiliary tract is being evaluated (10). For instance, several investigators (11) have detected the presence of Helicobacter-specific DNA (using the polymerase chain reaction) in samples obtained from subjects with primary sclerosing cholangitis. However, the successful culture of viable organisms from biliary epithelia has not been reproducible.

More recently, an increasing number of reports have considered the possibility that $H$ pylori infection of the stomach may have consequences for adverse health effects outside of the gastrointestinal tract (Table 1). For instance, multiple studies have considered the potential for an infectious etiology of coronary artery disease. However, the current consensus (based on available literature) does not provide support for the contention that there is a cause and effect relationship between $H$ pylori gastric infection and atherosclerotic heart 


\begin{tabular}{l}
$\begin{array}{l}\text { TABLE 1 } \\
\text { Purported extraintestinal manifestations of Helicobacter } \\
\text { pylori infection }\end{array}$ \\
$\begin{array}{ll}\text { Cardiovascular } & \text { Atherosclerotic heart disease, stroke } \\
\text { Neurological } & \text { Parkinson's disease, migraine } \\
\text { Autoimmune } & \text { Immune thrombocytopenic purpura, Raynaud's } \\
& \text { phenomenon, Sjogren's syndrome, diabetes mellitus } \\
\text { Dermatological } & \text { Chronic urticaria, angioedema, rosacea, alopecia areata } \\
\text { Others } & \text { Halitosis, hyperemesis gravidarum, anorexia of aging } \\
& \text { glaucoma, oral ulcers, urethritis }\end{array}$ \\
\hline
\end{tabular}

disease (reviewed by Gasbarrini et al [7]). Similar weaknesses in study design limit enthusiasm for supporting the contention that $H$ pylori is a causative agent in a variety of other purported disease conditions. For instance, just in the past year, $\mathrm{H}$ pylori infection has been considered a potential cause of nongonococcal urethritis (12), aphthous stomatitis (13) and glaucoma (14). However, the level of supporting evidence is limited and certainly insufficient for current consensus conferences to advocate therapeutic interventions in such clinical settings.

The present review will focus on reported extradigestive manifestations of $\mathrm{H}$ pylori infection in the pediatric age group (Table 2). A critical review of the available literature is provided, together with recommendations for updating current consensus conference recommendations based on advances in knowledge in the field.

\section{Sideropenic (refractory iron deficiency) anemia}

A series of case reports, both in children and adults, first indicated that $H$ pylori infection could be a potential cause of otherwise unexplained sideropenic anemia (reviewed by Barabino [15]). Sideropenic anemia that does not respond to supplemental iron therapy can resolve following successful eradication of $H$ pylori from the antrum of the stomach (16).

Subsequent case controlled studies have confirmed these findings by showing higher rates of $\mathrm{H}$ pylori infection in patients with unexplained sideropenic anemia compared with age- and sex-matched controls without iron deficiency (17). Lower iron stores are also evident in $H$ pylori-infected subjects compared with age- and sex-matched controls without gastric infection (18). Controlled studies confirm that eradication of $H$ pylori results in increased hemoglobin levels, whereas iron supplementation alone has no effect (19).

The biological explanation for $\mathrm{H}$ pylori infection causing sideropenic anemia remains uncertain. Initial considerations focused on occult blood loss due to chronic active superficial gastritis induced by H pylori (20). However, subsequent studies (21) have not confirmed evidence of occult blood loss. Infection with $H$ pylori may cause impairment in iron uptake and increases in iron demand. Hypoacidity because of pangastritis (21) and low ascorbic acid levels in the stomach of H pyloriinfected patients also could result in impaired duodenal iron absorption (22). In addition, gastric mucosa levels of lactoferrin, an iron-binding protein, are elevated in $\mathrm{H}$ pylori-infected patients with iron deficiency (23), indicating a possible role between increased lactoferrin sequestration and iron utilization by the organism. Alternatively, $\mathrm{H}$ pylori may compete with the infected host for available dietary iron. For example, $\mathrm{H}$ pylori possesses multiple iron acquisition systems, which can avidly and efficiently takeup iron available in the microenvironment of the lumen of the stomach (24).
TABLE 2

Reported extradigestive manifestations of Helicobacter pylori in infants, children and adolescents

Sideropenic (refractory iron deficiency) anemia
Immune thrombocytopenic purpura
Short stature
Impaired weight velocity
Diarrhea
Food allergy
Sudden infant death syndrome

Immune thrombocytopenic purpura

A subset of patients with chronic immune thrombocytopenic purpura will respond to eradication of $H$ pylori with an increase in platelet count (reviewed by Franchini and Veneri [25]). However, such a positive response has not been observed in every case series (26). The potential for molecular mimicry, with antiplatelet antibodies in serum recognizing the cytotoxinassociated gene A protein of $H$ pylori (27), provides a biological explanation for the apparent association. Reports in children with chronic idiopathic thrombocytopenic purpura provide conflicting results $(28,29)$. Accordingly, additional studies focusing on large numbers of children with chronic immune thrombocytopenic purpura (30) are warranted before guidelines are revised to include this entity as an extradigestive manifestation of $\mathrm{H}$ pylori infection.

\section{Short stature, impared weight velocity and diarrhea}

A number of prospective (31) and cross-sectional (32) studies suggest that $H$ pylori infection in children has an adverse effect on linear growth; however, other case-controlled studies have not supported such an assertion (33). Socioeconomic status likely plays a major confounding role in adversely influencing growth velocity. Sex may also prove to be a contributing factor; for example, Richter et al (32) found that only boys with $\mathrm{H}$ pylori infection were shorter and had lower weight gain compared with noninfected controls. Additional reports indicate an adverse effect on body weight, but no effect on linear growth (reviewed by Sherman and Macarthur [34]). The impact of maternal $\mathrm{H}$ pylori infection on impaired growth of the fetus in utero has also been suggested (35).

Biological explanations for a reduction in growth velocity remain to be defined. Initial considerations raised the potential that young children infected with $H$ pylori were at an increased risk for episodes of diarrhea; a known risk factor for impaired growth with repeated episodes and associated under-nutrition. Although some studies support such a contention (36), other reports indicate no such effect (37-40). Indeed, other investigators suggest that $H$ pylori infection might even protect children against infection from other intestinal pathogens causing diarrheal disease (41). Choe et al (42) suggested that iron deficiency induced by $\mathrm{H}$ pylori infection, rather than the bacterial infection per se, accounts for short stature in Korean children between 10 and 15 years of age.

An alternative explanation for the potential impact of $\mathrm{H}$ pylori infection on growth velocity in children could be effects of the organism (or resulting gastritis) on hormones that control appetite. Recent findings demonstrate that the stomach is a source of both ghrelin and leptin. Nwokolo et al (43) found that plasma ghrelin levels increased in 10 healthy adult 
patients after successful eradication of $H$ pylori. However, this finding requires confirmation because another study did not find differences in levels of plasma ghrelin between $24 \mathrm{H}$ pyloriinfected female patients and 15 uninfected women matched for body mass index (44). Azuma et al (45) showed that eradication of $\mathrm{H}$ pylori infection resulted in a reduction of gastric leptin, even though serum levels of the hormone were not altered. If confirmed by future studies conducted in children, the net effect of $\mathrm{H}$ pylori colonization and chronic active gastritis on increasing levels of leptin and lowered ghrelin could be to impair appetite and reduce energy intake (the potential for an impairment of body mass index). Before firm guidelines regarding the role of $\mathrm{H}$ pylori infection in growth are considered, additional prospective controlled studies need to be conducted to precisely delineate the factors involved in impairing body weight and reducing linear height.

\section{Food allergies}

One study has reported higher $H$ pylori-specific immunoglobulin $G$ titres in serum samples obtained from 30 children with food allergies, compared with an equal number of subjects with either asthma or inflammatory bowel disease (46). A provocative review by Matysiak-Budnik and Heyman (47) considers potential underlying mechanisms which may explain this apparent association. Additional confirmatory studies from other centres are required before considering the merits of undertaking intervention studies to determine if altered gastric permeability and atopic symptoms might be reversible following H pylori eradication.

\section{Sudden infant death syndrome}

A speculative report by Pattison and Marshall (48) raised the potential that sudden infant death syndrome (SIDS) could be due to $H$ pylori infection in infants. This hypothesis appeared to be supported by a subsequent publication (49) which reported the identification of Helicobacter-like DNA in the respiratory tract of autopsy materials obtained from infants who died of SIDS, but not in a smaller number of controls who were older in age. That report raised considerable alarm, guilt and concern among parents who had previously

\section{REFERENCES}

1. Allen P. What's the story H pylori? Lancet 2001;357:694.

2. Blaser MJ, Atherton JC. Helicobacter pylori persistence: Biology and disease. J Clin Invest 2004;113:321-33.

3. Suerbaum S, Michetti P. Helicobacter pylori infection. N Engl J Med 2002;347:1175-86.

4. Uemura N, Okamoto S, Yamamoto S, et al. Helicobacter pylori infection and the development of gastric cancer. N Engl J Med 2001;345:784-9.

5. Peek Jr RM, Blaser MJ. Helicobacter pylori and gastrointestinal tract adenocarcinomas. Nat Rev Cancer 2002;2:28-37.

6. Yoon SS, Coit DG, Portlock CS, Karpeh MS. The diminishing role of surgery in the treatment of gastric lymphoma. Ann Surg 2004;240:28-37.

7. Gasbarrini A, Carloni E, Gasbarrini G, Menard A. Helicobacter pylori and extragastric diseases - other Helicobacters. Helicobacter 2003;8(Suppl 1):68-76.

8. Burich A, Hershberg R, Waggie K, et al. Helicobacter-induced inflammatory bowel disease in IL-10 and T cell-deficient mice. Am J Physiol Gastrointest Liver Physiol 2001;281:G764-78.

9. Whary MT, Fox JG. Natural and experimental Helicobacter infections. Comp Med 2004;54:128-58.

10. Fallone CA, Tran S, Semret M, Discepola F, Behr M, Barkun AN. Helicobacter DNA in bile: Correlation with hepato-biliary diseases. Aliment Pharmacol Ther 2003;17:453-8. suffered the tragedy of an otherwise healthy baby dying suddenly and unexpectedly.

Following that report, a subsequent editorial (50) and letters (51) scathed the analysis, with much concern addressing the lack of appropriate controls and the absence of culture of the organism; that is, the molecular approach employed may well have provided false-positive results. Notably, two subsequent studies $(52,53)$ failed to demonstrate the presence of $H$ pylori organisms in the stomach and trachea of babies who had died of SIDS. In addition, an equal number of subjects with and without SIDS tested positive for the presence of $\mathrm{H}$ pylori DNA using the polymerase chain reaction. Thus, it appears likely that the molecular approach employed to detect $H$ pylori, in fact, does result in false-positive findings. Alternatively, postmortem cross-contamination could have occurred during tissue handling and processing.

\section{CONCLUSIONS AND RECOMMENDATIONS}

Sufficient evidence is now available to consider $H$ pylori infection a cause of otherwise unexplained sideropenic anemia. In such a clinical setting, once gluten-sensitive enteropathy has been excluded as an alternate explanation, it seems reasonable to consider a test-and-treat strategy for H pylori infection. Clinical practice guidelines and treatment recommendations should be updated and revised accordingly to reflect that $H$ pylori can indeed cause sideropenic anemia in infected humans.

Currently, available data are not sufficiently compelling to consider adding other reported extradigestive manifestations of H pylori infection to the list of conditions in which a test-andtreat strategy should be considered. On the other hand, when new and compelling information arises in the context of welldesigned studies with appropriate control and comparison groups, there will be a need to reassess this cautious recommendation in the future.

ACKNOWLEDGEMENTS: FYH Lin is the recipient of a Canadian Institutes of Health Research - Industry (Canadian Association of Gastroenterology/AstraZeneca Canada) Research Initiative Award. PM Sherman is the recipient of a Canada Research Chair in Gastrointestinal Disease.

11. Nilsson HO, Taneera J, Castedal M, Glatz E, Olsson R, Wadstrom T. Identification of Helicobacter pylori and other Helicobacter species by PCR, hybridization, and partial DNA sequencing in human liver samples from patients with primary sclerosing cholangitis or primary biliary cirrhosis. J Clin Microbiol 2000;38:1072-6.

12. Eslick GD. Non-gonococcal urethritis, Helicobacter pylori infection and fellatio: A new menage a trois? Microbiology 2004;150:520-2.

13. Fritscher AM, Cherubini K, Chies J, Dias AC. Association between Helicobacter pylori and recurrent aphthous stomatitis in children and adolescents. J Oral Pathol Med 2004;33:129-32.

14. Kountouras J, Zavos C, CHatzopoulos D. Induction of apoptosis as a proposed pathophysiological link between glaucoma and Helicobacter pylori infection. Med Hypothesis 2004;62:378-81.

15. Barabino A. Helicobacter pylori-related iron deficiency anemia: A review. Helicobacter 2002;7:71-5.

16. Kostaki M, Fessatou S, Karpathios T. Refractory iron-deficiency anaemia due to silent Helicobacter pylori gastritis in children. Eur J Pediatr 2003;162:177-9.

17. Nahon S, Lahmek P, Massard J, et al. Helicobacter pylori-associated chronic gastritis and unexplained iron deficiency anemia: A reliable association? Helicobacter 2003;8:573-7.

18. Baysoy G, Ertem D, Ademoglu E, Kotiloglu E, Keskin S, Pehlivanoglu E. Gastric histopathology, iron status and iron 
deficiency anemia in children with Helicobacter pylori infection. J Pediatr Gastroenterol Nutr 2004;38:146-51.

19. Choe YH, Kwon YS, Jung MK, Kang SK, Hwang TS, Hong YC. Helicobacter pylori-associated iron-deficiency anemia in adolescent female athletes. J Pediatr 2001;139:100-4.

20. Yip R, Limburg PJ, Ahlquist DA, et al. Pervasive occult gastrointestinal bleeding in an Alaska native population with prevalent iron deficiency: Role of Helicobacter pylori gastritis. JAMA 1997;277:1135-9.

21. Sarker SA, Davidsson L, Mahmud H, et al. Helicobacter pylori infection, iron absorption, and gastric acid secretion in Bangladeshi children. Am J Clin Nutr 2004;80:149-53.

22. Ashorn M. Acid and iron disturbances related to Helicobacter pylori infection. J Pediatr Gastroenterol Nutr 2004;38:137-9.

23. Choe YH, Oh YJ, Lee NG, et al. Lactoferrin sequestration and its contribution to iron-deficiency anemia in Helicobacter pyloriinfected gastric mucosa. J Gastroenterol Hepatol 2003;18:980-5.

24. Velayudhan J, Hughes NJ, McColm AA, et al. Iron acquisition and virulence in Helicobacter pylori: A major role for FeoB, a highaffinity ferrous iron transporter. Mol Microbiol 2000;37:274-86.

25. Franchini M, Veneri D. Helicobacter pylori and immune thrombocytopenic purpura. Haematologica 2003;88:1087-91.

26. Michel M, Cooper N, Jean C, Frissora C, Bussel JB. Does Helicobacter pylori initiate or perpetuate immune thrombocytopenic purpura? Blood 2004;103:890-6.

27. Takahashi T, Yujiri T, Shinohara K, et al. Molecular mimicry by Helicobacter pylori CagA protein may be involved in the pathogenesis of $\mathrm{H}$ pylori-associated chronic idiopathic thrombocytopenic purpura. Br J Hematol 2004;124:91-6.

28. Jaing TH, Yang CP, Hung IJ, Chiu CH, Chang KW. Efficacy of Helicobacter pylori eradication on platelet recovery in children with chronic idiopathic thrombocytopenic purpura. Acta Paediatr 2003;92:1153-7.

29. Rajantie J, Klemola T. Helicobacter pylori and idiopathic thrombocytopenic purpura in children. Blood 2003;101:1660.

30. Kuhne T, Buchanan GR, Zimmerman S, et al; Intercontinental Childhood ITP Study Group. A prospective comparative study of 2540 infants and children with newly diagnosed idiopathic thrombocytopenic purpura (ITP) from the Intercontinental Childhood ITP Study Group. J Pediatr 2003;143:605-8.

31. Bravo LE, Mera R, Reina JC, et al. Impact of Helicobacter pylori infection on growth of children: A prospective cohort study. J Pediatr Gastroenterol Nutr 2003;37:614-9.

32. Richter T, Richter T, List S, et al. Five- to 7-year-old children with Helicobacter pylori infection are smaller than Helicobacternegative children: A cross-sectional population-based study of 3,315 children. J Pediatr Gastroenterol Nutr 2001;33:472-5.

33. Ozcay F, Demir H, Ozen H, et al. Normal growth in young children with Helicobacter pylori infection. J Pediatr Gastroenterol Nutr 2002;35:102.

34. Sherman PM, Macarthur C. Current controversies associated with Helicobacter pylori infection in the pediatric population. Front Bioscience 2001;6:E187-92.
35. Eslick GD, Yan P, Xia HH, Murray M, Spurrett B, Talley NJ. Foetal intrauterine growth restrictions with Helicobacter pylori infection. Aliment Pharmacol Ther 2002;16:1677-82.

36. Passaro DJ, Taylor DN, Meza R, Cabrera L, Gilman RH, Parsonnet J. Acute Helicobacter pylori infection is followed by an increase in diarrheal disease among Peruvian children. Pediatrics 2001;108:E87.

37. Rahman MM, Mahalanabis D, Sarker SA, et al. Helicobacter pylori colonization in infants and young children is not necessarily associated with diarrhoea. J Trop Pediatr 1998;44:283-7.

38. Isenbarger DW, Bodhidatta L, Hoge CW, et al. Prospective study of the incidence of diarrheal disease and Helicobacter pylori infection among children in an orphanage in Thailand. Am J Trop Med Hyg 1998;59:796-800.

39. Castro-Rodriguez JA, Leon-Barua R, Penny M. Helicobacter pylori is not a determinant factor of persistent diarrhoea or malnutrition in Peruvian children. Trans R Soc Trop Med Hyg 1999;93:537-9.

40. Passaro DJ, Taylor DN, Gilman RH, Cabrera L, Parsonnet J. Growth slowing after acute Helicobacter pylori infection is agedependent. J Pediatr Gastroenterol Nutr 2002;35:522-6.

41. Rothenbacher D, Blaser MJ, Bode G, Brenner H. Inverse relationship between gastric colonization of Helicobacter pylori and diarrheal illnesses in children: Results of a population-based crosssectional study. J Infect Dis 2000;182:1446-9.

42. Choe YH, Kim SK, Hong YC. Helicobacter pylori infection with iron deficiency anaemia and subnormal growth at puberty. Arch Dis Child 2000;82:136-40.

43. Nwokolo CU, Freshwater DA, O'Hare P, Randeva HS. Plasma ghrelin following cure of Helicobacter pylori. Gut 2003;52:637-40.

44. Gokcel A, Gumurdulu Y, Kayaselcuk F, et al. Helicobacter pylori has no effect on plasma ghrelin levels. Eur J Endocrinol 2003;148:423-6.

45. Azuma T, Suto H, Ito Y, et al. Gastric leptin and Helicobacter pylori infection. Gut 2001;49:324-9.

46. Corrado G, Luzzi I, Lucarelli S, et al. Positive association between Helicobacter pylori infection and food allergy in children. Scand J Gastroenterol 1998;33:1135-9.

47. Matysiak-Budnik T, Heyman M. Food allergy and Helicobacter pylori. J Pediatr Gastroenterol Nutr 2002;34:5-12.

48. Pattison CP, Marshall B. Proposed link between Helicobacter pylori and sudden infant death syndrome. Med Hypothesis 1997;49:365-9.

49. Kerr JR, Al-Khattaf A, Barson AJ, Burnie JP. An association between sudden infant death syndrome (SIDS) and Helicobacter pylori infection. Arch Dis Child 2000;83:429-34.

50. Rowland M, Drumm B. Helicobacter pylori and sudden-infant-death syndrome. Lancet 2001;357:327.

51. Murphy MS. Helicobacter pylori. Arch Dis Child 2001;84:525.

52. Elitsur Y, Btriest W, Sabet Z, Neace C, Jiang C, Thomas E. Is sudden infant death syndrome associated with Helicobacter pylori infection in children? Helicobacter 2000;5:227-31.

53. Ho GY, Windsor HM, Snowball B, Marshall BJ. Helicobacter pylori is not the cause of sudden infant death syndrome (SIDS). Am J Gastroenterol 2001;96:3288-94. 


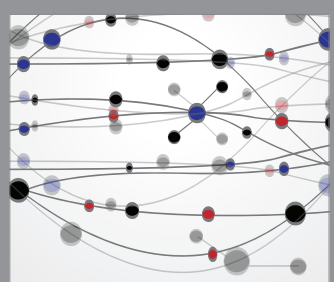

The Scientific World Journal
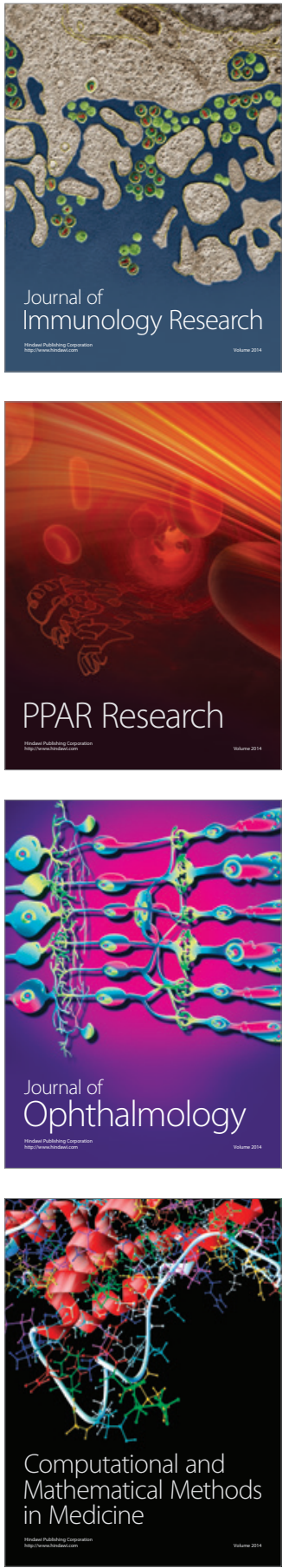

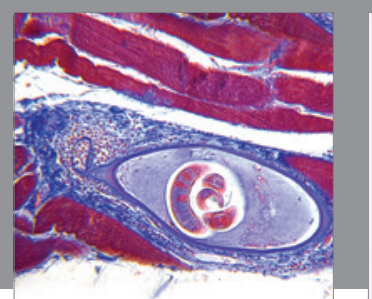

Gastroenterology Research and Practice

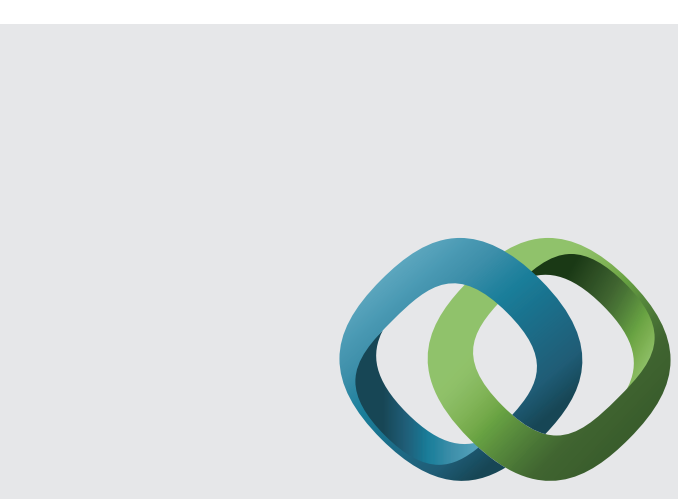

\section{Hindawi}

Submit your manuscripts at

http://www.hindawi.com
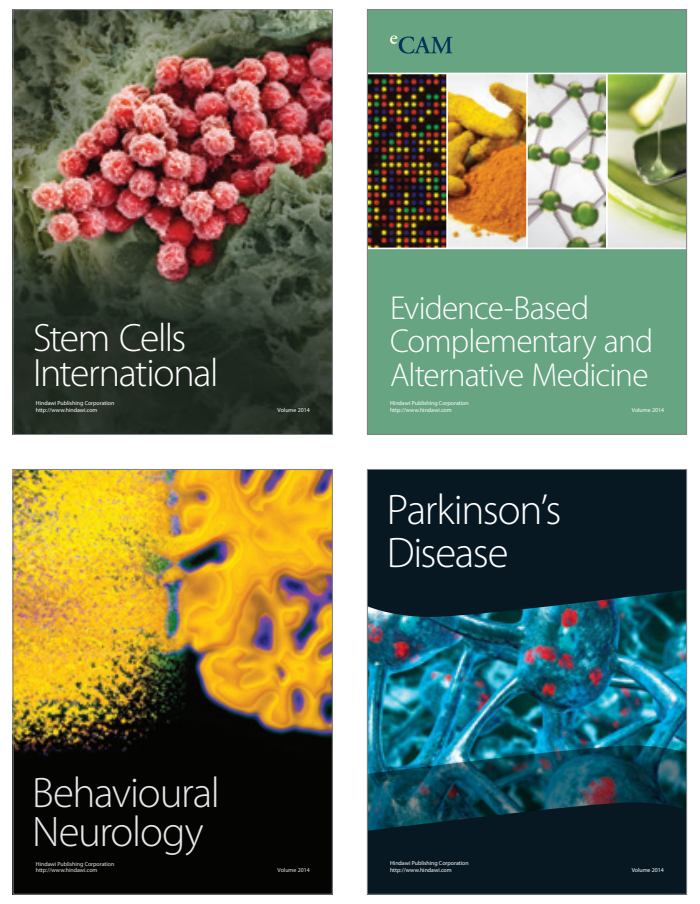
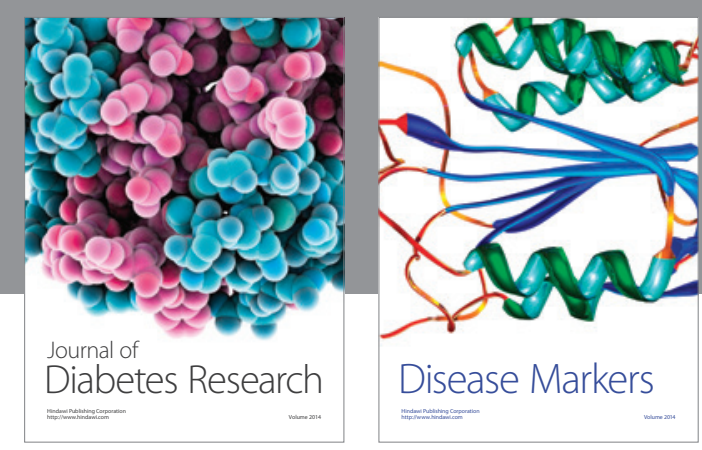

Disease Markers
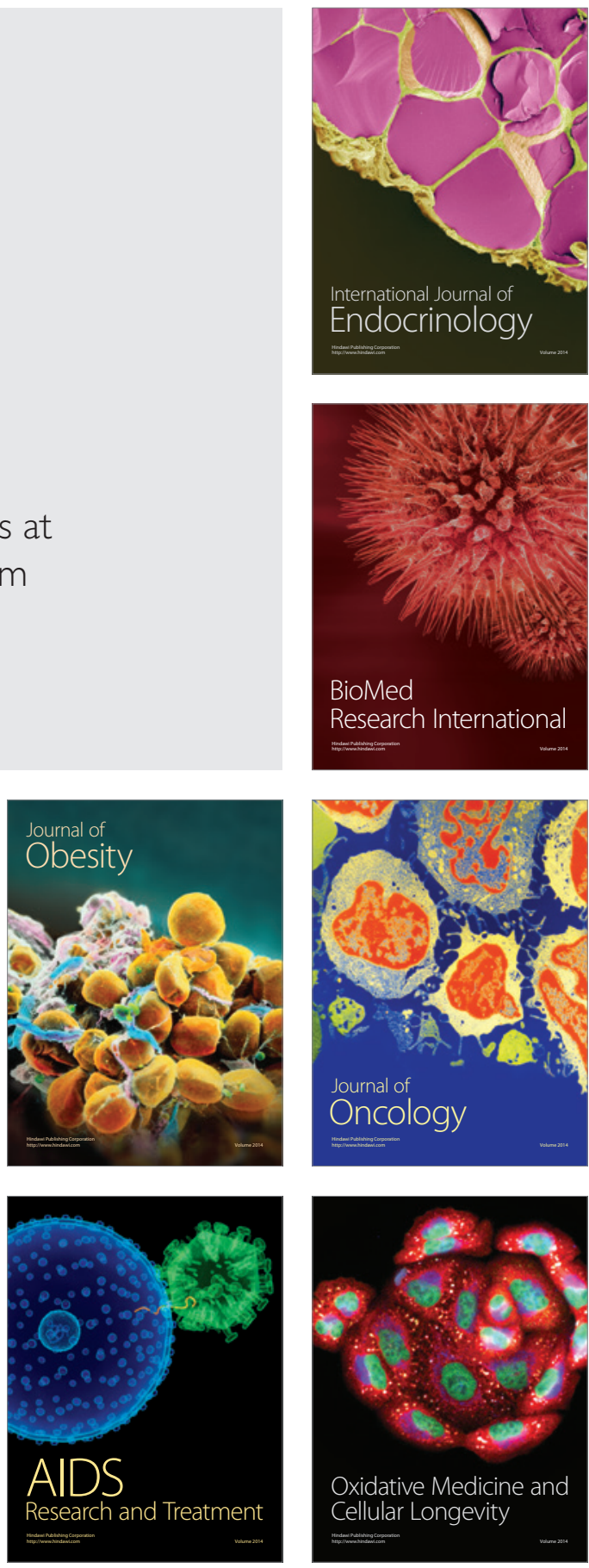